\title{
Antibacterial effect of acidic ionized water on horse wounds bacterial isolates
}

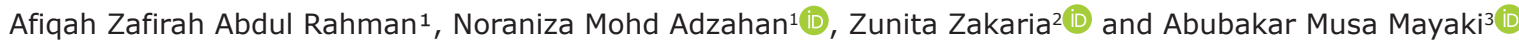

1. Department of Farm and Exotic Animal Medicine and Surgery, Faculty of Veterinary Medicine, Universiti Putra Malaysia, 43400 UPM Serdang, Selangor, Malaysia; 2. Department of Veterinary Pathology and Microbiology, Faculty of Veterinary Medicine, Universiti Putra Malaysia, 43400 UPM Serdang, Selangor, Malaysia; 3. Department of Veterinary Medicine, Faculty of Veterinary Medicine, Usmanu Danfodiyo University, Sokoto, PMB2346, City Campus, Sokoto, Nigeria. Corresponding author: Noraniza Mohd Adzahan, e-mail: noraniza@upm.edu.my

Co-authors: AZAR: afizafirah95@gmail.com, ZZ: zunita@upm.edu.my, AMM: mayaki.abubakar@udusok.edu.ng Received: 09-12-2020, Accepted: 25-03-2021, Published online: 10-05-2021

doi: www.doi.org/10.14202/vetworld.2021.1128-1132 How to cite this article: Rahman AZA, Adzahan NM, Zakaria Z, Mayaki AM (2021) Antibacterial effect of acidic ionized water on horse wounds bacterial isolates, Veterinary World, 14(5): 1128-1132.

\begin{abstract}
Background and Aim: Horse wounds can be easily infected with bacteria depending on the nature of its cause such as laceration, abrasion, or puncture as well as the nature of its environment. Various treatments are available in managing open wounds, including the usage of topical antibiotics and antiseptics. However, antibiotic resistance has been a major concern attributed with chronic wound infection. The aim of this study was to test the efficacy of ionized water at different $\mathrm{pH}$ against the growth of common bacteria from horse wounds.
\end{abstract}

Materials and Methods: Ten swab samples from equine infected wounds were collected and bacteria isolation and

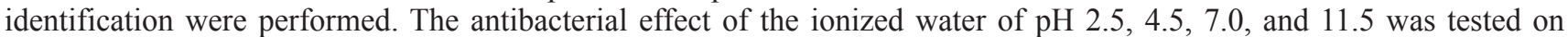
Staphylococcus aureus, Staphylococcus pseudintermedius, Staphylococcus intermedius, Escherichia coli, Pantoea agglomerans, and Klebsiella pneumoniae. The time-kill profiles of the ionized waters were determined at time 0, 2, 4, 6, and $8 \mathrm{~h}$.

Results: Ionized water of $\mathrm{pH} 2.5$ and 4.5 showed antibacterial activity against $S$. aureus, S. pseudintermedius, and S. intermedius with significant $(\mathrm{p}>0.05)$ reduction in colony-forming unit $/ \mathrm{mL}$ within $2-8 \mathrm{~h}$. The degree of bactericidal effect of the acidic ionized water differs between the species with $S$. intermedius more susceptible. However, there was no antibacterial effect at $\mathrm{pH} 2.5,4.5,7.0$, and 11.5 on the Gram-negative bacteria tested.

Conclusion: Ionized water of $\mathrm{pH} 2.5$ and 4.5 is effective in minimizing the growth of Gram-positive bacteria; thus it could be of clinical importance as an antiseptic for surface wound lavage in horses.

Keywords: bacterial growth, ionized water, horse, wounds.

\section{Introduction}

Wounds mostly occur due to trauma resulting in the breakage of integrity of dermal layer, thus causing it to be exposed to external environment. Wounds in horses have the tendency to get infected due to various environmental factors such as fecal contamination, dirt, and plant debris, as well as foreign bodies [1,2]. Due to the risk of infection, the main purpose of wound management is to reduce presence of bacteria on the healing tissue. To achieve this, wound lavage, debridement, dressing, and bandaging are the methods employed in wound management apart from the use of antibiotic therapy [2]. However, the existence of antimicrobial resistance, particularly multidrug resistance bacteria, has made the use of antibiotics for wound management challenging [3]. Furthermore, most of

Copyright: Rahman, et al. Open Access. This article is distributed under the terms of the Creative Commons Attribution 4.0 International License (http://creativecommons.org/licenses/ by/4.0/), which permits unrestricted use, distribution, and reproduction in any medium, provided you give appropriate credit to the original author(s) and the source, provide a link to the Creative Commons license, and indicate if changes were made. The Creative Commons Public Domain Dedication waiver (http:// creativecommons.org/publicdomain/zero/1.0/) applies to the data made available in this article, unless otherwise stated. the disinfectant or antiseptic solutions used are chemical based with varying degrees of toxicity such as skin irritation, allergic reaction, and occupational asthma in human [4].

The antibacterial effect of electrolyzed and ionized waters of acidic $\mathrm{pH}$ on surface microbial growth reported by previous studies suggests that these substances can be used as an antiseptic or disinfectant. More importantly, healing of cutaneous open wound and control of burn wound infection in rats have been facilitated by ionized and electrolyzed oxidized water, respectively $[5,6]$. The antibacterial effect of electrolyzed water has been mostly reported on raw food products in food industries as well as animal transport vehicles [7-9].

There is insufficient research on ionized water in veterinary practice. It is our belief that ionized water depending on the $\mathrm{pH}$ may serve as wound surface lavage solution that can control bacterial infection that is associated with chronic non-healing wound in horses. We, therefore, aim in this study to investigate the effect of ionized water at different $\mathrm{pH}$ at different time against the growth of bacterial isolate from horse wounds. 


\section{Materials and Methods}

\section{Ethical approval}

All procedures were performed according to the guideline approved by the Institutional Animal Care and Use Committee, Universiti Putra Malaysia (UPM/ IACUC/AUP-U073/2018).

\section{Study period and location}

This study was conducted from August to September 2018. All the horses included in this study were cases presented at the University Veterinary Hospital (UVH) Faculty of Veterinary Medicine, Universiti Putra Malaysia (UPM). The bacteriological procedures were performed at the Bacteriology Laboratory, Faculty of Veterinary Medicine, UPM.

\section{Sample collection}

Wound swabs were collected from 10 horses with different types of wound lesion. The wound was first rinsed with sterile saline and the swabbing was done with a sterile swab using Levine's technique of wound sampling. The swabs were then placed in a Cary Blair transport medium and transported on ice.

\section{Isolation and identification of bacteria}

Each individual swab sample were streaked onto blood and MacConkey agars and incubated at $37^{\circ} \mathrm{C}$ for $24 \mathrm{~h}$. The individual bacterial colony from each agar plate was subcultured on blood and MacConkey agar at $37^{\circ} \mathrm{C}$ for $24 \mathrm{~h}$ to obtain a pure culture. Biochemical tests were conducted on the pure culture to identify the bacterial species.

\section{Preparation of ionized water}

Ionized water was prepared using a conventional water ionizer. The ionizer setting was manipulated to produce ionized water of $\mathrm{pH} 2.4,4.5,7.0$, and 11.5.

\section{Time-kill assay}

The top three isolated Gram-positive (Staphylococcus aureus, Staphylococcus pseudintermedius, and Staphylococcus intermedius) and Gram-negative bacteria (Escherichia coli, Pantoea agglomerans, and Klebsiella pneumoniae) were selected to assess the time-kill effect of the ionized waters of different $\mathrm{pH}$ tested. The respective bacteria colonies were mixed with sterile distilled water and standardized using McFarland 0.5 to obtain a colony-forming unit (CFU) of $1.5 \times 10^{8}$. The bacteria suspension $(1.0 \mathrm{~mL})$ was then added into respective test tube containing ionized water at different $\mathrm{pH}$. Sterile distilled water was used as control. The suspensions were allowed to settle for $0,2,4,6$, and $8 \mathrm{~h}$, and for every time interval, $0.1 \mathrm{~mL}$ of the bacteria suspension was taken from respective test tubes and plated onto nutrient agar which was incubated at $37^{\circ} \mathrm{C}$ for 24 h. All cultural analyses for each respective time were done in triplicates. The time-kill analysis to assess the bactericidal effect of the ionized water was determined by manually counting the bacteria colony growth in each agar for the time $0,2,4,6$, and $8 \mathrm{~h}$ and the CFU/mL calculated. The bactericidal effect of the ionized water is considered when the decrease in $\mathrm{CFU} / \mathrm{mL}$ of the bacteria growth in relation to the initial culture inoculum was $>3 \log 10$, indicating $99.9 \%$ killing of the inoculum.

\section{Statistical analysis}

The bacterial isolates were presented using descriptive statistics. The average of the CFU/mL of the triplicate cultural analysis for each time interval was calculated and used for the time-kill curve. The difference in $\log \mathrm{CFU} / \mathrm{mL}$ between the control and the different $\mathrm{pH}$ ionized water at times $0,2,4,6$, and $8 \mathrm{~h}$ were compared using Student's t-test. Statistical analyses were performed using GraphPad Prism version 8 (GraphPad Software, California, USA), with $\mathrm{p}<0.05$ considered as statistically significant.

\section{Results}

\section{Bacteria isolation}

The cultural isolation of bacteria from the horse wound swab samples yielded 49 isolates comprising 20 bacterial species with $51 \%$ being Gram-negative and $49 \%$ being Gram-positive species (Table-1). The prominent species are S. aureus $(26.53 \%)$, E. coli (16.33\%), and P. agglomerans (14.29\%).

\section{Time-kill assay}

The prominent Gram-positive: $S$. aureus, S. pseudintermedius, and S. intermedius, and Gramnegative: E. coli, $P$. agglomerans, and $K$. pneumoniae

Table-1: Bacterial species isolated from equine wound swab samples.

\begin{tabular}{|c|c|c|c|}
\hline $\begin{array}{l}\text { Class of } \\
\text { bacteria }\end{array}$ & Bacterial species & $\begin{array}{l}\text { Number of } \\
\text { isolates }\end{array}$ & $\begin{array}{l}\quad \% \\
\text { isolates }\end{array}$ \\
\hline \multirow{13}{*}{$\begin{array}{l}\text { Gram-positive } \\
\text { bacteria }\end{array}$} & Staphylococcus aureus & 13 & 26.53 \\
\hline & Staphylococcus & 3 & 6.12 \\
\hline & pseudintermedius & & \\
\hline & Staphylococcus & 2 & 4.08 \\
\hline & intermedius & & \\
\hline & $\begin{array}{l}\text { Streptococcus equi } \\
\text { ssp. zooepidemicus }\end{array}$ & 1 & 2.04 \\
\hline & Streptococcus iniae & 1 & 2.04 \\
\hline & Streptococcus equi & 1 & 2.04 \\
\hline & Streptococcus & 1 & 2.04 \\
\hline & equisimilis & & \\
\hline & Listeria & 1 & 2.04 \\
\hline & monocytogenes & & \\
\hline & Bacillus cereus & 1 & 2.04 \\
\hline \multirow{13}{*}{$\begin{array}{l}\text { Gram-negative } \\
\text { bacteria }\end{array}$} & Escherichia coli & 8 & 16.33 \\
\hline & Pantoea agglomerans & 7 & 14.29 \\
\hline & Klebsiella pneumoniae & 2 & 4.08 \\
\hline & $\begin{array}{l}\text { Plesiomonas } \\
\text { shigelloides }\end{array}$ & 1 & 2.04 \\
\hline & Proteus mirabilis & 1 & 2.04 \\
\hline & Yersinia intermedia & 1 & 2.04 \\
\hline & Yersinia frederiksenii & 1 & 2.04 \\
\hline & Pseudomonas & 1 & 2.04 \\
\hline & aeruginosa & & \\
\hline & Klebsiella sp. & 1 & 2.04 \\
\hline & Enterobacter cloacae & 1 & 2.04 \\
\hline & Vibrio & 1 & 2.04 \\
\hline & parahaemolyticus & & \\
\hline
\end{tabular}


bacterial isolates were used for the assessment of antibacterial effect of acidic and alkaline ionized water.

The time-kill assay on Gram-positive bacteria showed that ionized water at $\mathrm{pH} 7$ and 11.5 were ineffective against the three bacterial species with no significant reduction in $\mathrm{CFU} / \mathrm{mL}$ observed when compared to the control over the $8 \mathrm{~h}$ period. However, ionized water at $\mathrm{pH} 2.5$ and 4.5 showed antibacterial activity against $S$. aureus, $S$. pseudintermedius, and $S$. intermedius with significant $(\mathrm{p}>0.05)$ reduction in $\mathrm{CFU} / \mathrm{mL}$ from 2 to $8 \mathrm{~h}$ when compared to the control (Figure-1a-c). There was no significant difference in the antibacterial activity at $\mathrm{pH} 2.5$ and 4.5 against $S$. aureus, $S$. pseudintermedius, and $S$. intermedius. However, the reduction of the bacteria cells was higher at $\mathrm{pH} 4.5$ than at $\mathrm{pH} 2.5$.

When comparing the antibacterial susceptibility of the three organisms to ionized water at $\mathrm{pH}$ 2.5 and 4.5, a bactericidal effect of $\mathrm{pH} 2.5$ and 4.5 with $99.99 \%$ kill of $S$. aureus inoculum was observed between 4 and 8 h post-inoculation (Figure-1a). For S. pseudintermedius, bactericidal effect was observed at pH 2.5 and 4.5 between 6 and $8 \mathrm{~h}$, and 4 and $8 \mathrm{~h}$, respectively (Figure-1b). However, S. intermedius was more susceptible with $99.99 \%$ kill of the bacteria observed during the $2^{\text {nd }} \mathrm{h}$ and no bacteria growth seen over the remaining $6 \mathrm{~h}$ (Figure-1c).

Contrastingly, all the ionized water at different $\mathrm{pH}$ tested on E. coli, P. agglomerans, and K. pneumoniae showed ineffective antibacterial activities (Figure-2). Although there was slight reduction in $\mathrm{CFU} / \mathrm{mL}$ of each bacterial species compared to the control, the highest reduction $(50-59 \%)$ relative to the initial inoculum of E. coli, P. agglomerans, and $K$. pneumoniae was $<3 \log 10$, indicating that the ionized water at $\mathrm{pH} 2.5,4.5,7$, and 11.5 has no bactericidal effect on the bacteria growth inhibition.

\section{Discussion}

Wounds in horses are highly contaminated with microbial pathogens. The bacterial isolates from the wound samples are similar to earlier studies with Staphylococcus been the most genus identified, followed by $E$. coli $[1,10]$. Since the colonization of these organisms, particularly Staphylococcus spp., could lead to chronic wound infection, the antibacterial effect of ionized water at different $\mathrm{pH}$ was tested on some selected species as well as Gram-negative bacterial species. Although, studies have shown that electrolyzed water possesses an effective antibacterial activity against common surface bacterial isolate like $S$. aureus $[11,12]$, this is the first report on the effects of ionized water on bacterial isolates of equine wounds.

In the present study, significant bactericidal activity of ionized water $\mathrm{pH} 2.5$ and 4.5 was demonstrated on $S$. aureus, $S$. pseudintermedius, and $S$. intermedius using time-kill measurements. $S$. aureus decreased by $99 \%$ in the initial $2 \mathrm{~h}$, and within $4-8 \mathrm{~h}$, bactericidal effect with $99.99 \%$ kill was observed. Similarly, the percentage $\log$ reduction of $S$. pseudintermedius due to $\mathrm{pH} 4.5$ was $99 \%$ at the $2 \mathrm{~h}$ and $99.99 \%$ from 6 to 8 h. In the case of ionized water $\mathrm{pH} 2.5$ on S. pseudintermedius, the percentage reduction was $99 \%$ at the 4 $\mathrm{h}$ post-inoculation and $99.99 \%$ within $6-8 \mathrm{~h}$. However, the susceptibility of $S$. intermedius to the acidic $\mathrm{pH}$ was much higher with $99.99 \%$ killing of the bacteria observed in the first $2 \mathrm{~h}$ and complete bacteria growth inhibition was seen over the remaining $6 \mathrm{~h}$. Unlike acidic electrolyzed water which its bactericidal effect is attributed to hypochlorous acid, the antibacterial effect of acidic ionized water could be as a result of reactive oxygen species due to free radicals produce at anode chamber during ionization reaction. Contrary

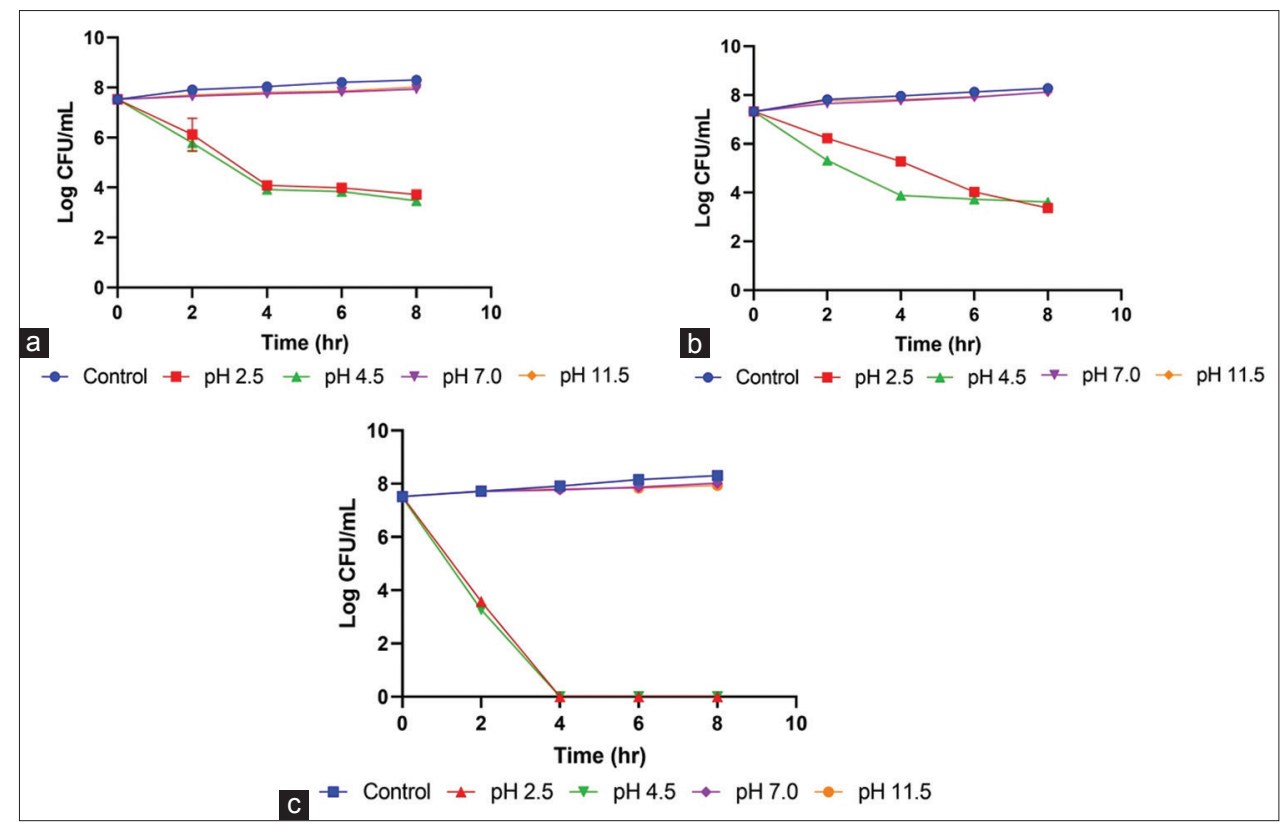

Figure-1: Antibacterial effect of different pH ionized waters on prominent Gram-positive bacterial isolated from horses wound. (a) Staphylococcus aureus, (b) Staphylococcus pseudintermedius, (c) Staphylococcus intermedius. 


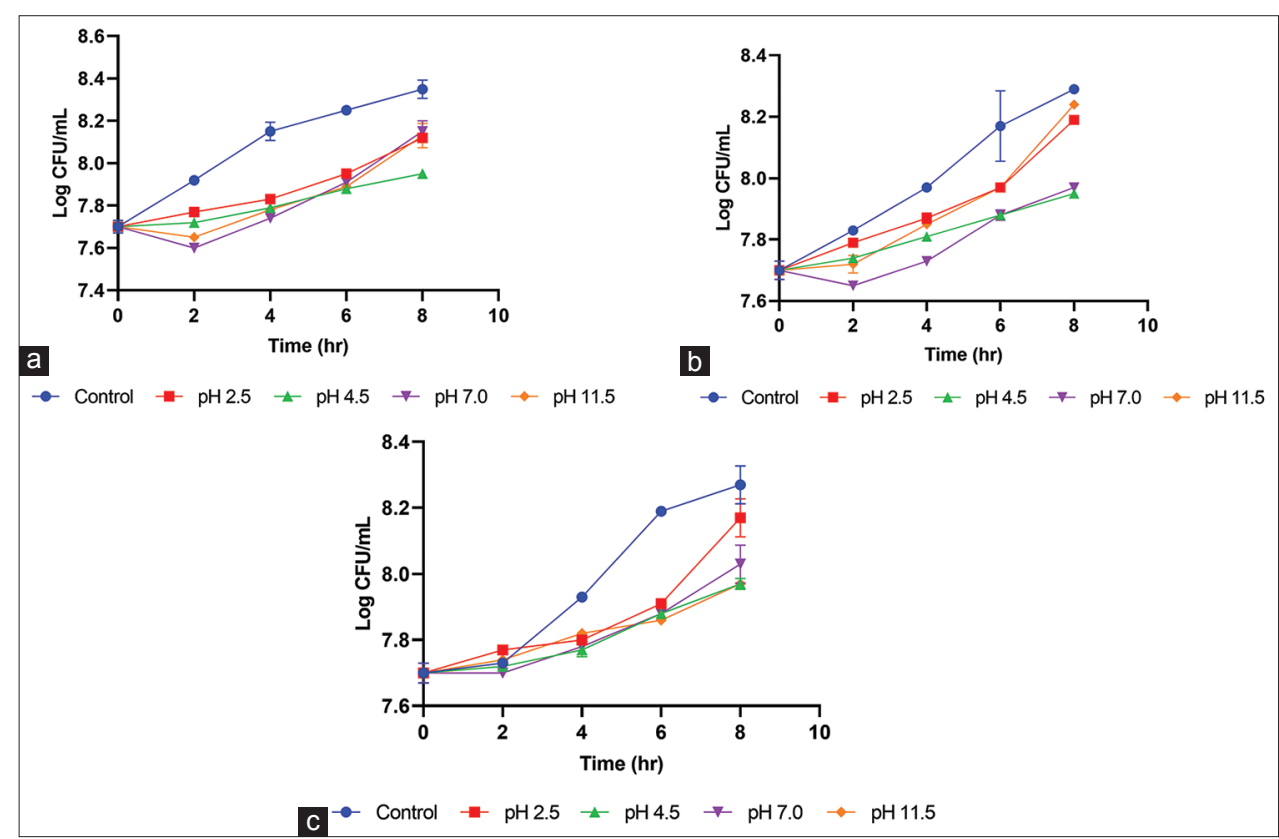

Figure-2: Time-kill measurements of ionized waters of different $\mathrm{pH}$ on Gram-negative bacterial isolated from horses wound. (a) Escherichia coli, (b) Pantoea agglomerans, and (c) Klebsiella pneumoniae.

to the acidic ionized water, $\mathrm{pH} 7.0$ and 11.5 caused a relatively low reduction with $\log$ difference relative to the initial bacteria inoculum $<3 \log 10$, indicating no bactericidal effect on the tested Staphylococcus species at both $\mathrm{pH}$. The highest percentage reduction observed for $\mathrm{pH} 7$ and 11.5 on $S$. aureus was $58.3 \%$ and $57.3 \%$ within the $8 \mathrm{~h}$ and $6 \mathrm{~h}$, respectively. Similarly, $51.0 \%$ and $55.3 \%$ reduction in S. intermedius was seen within 6-8 $\mathrm{h}$, while much lower reduction of $32 \%$ was observed for S. pseudintermedius at the end of $8 \mathrm{~h}$. The difference in the effect of ionized water among Staphylococcus species could be due to genetic variants and cellular properties that the subspecies possesses. The ability to change membrane composition through the alteration of the membrane fatty acid sequence in response to the decrease or increase in environmental $\mathrm{pH}$ has been acknowledged [13]. Furthermore, some pathogenic bacteria also possess adaptive acid tolerance response, like the ability of the bacteria to change protein expression when exposed to acidic environment $[14,15]$. The significant higher effect at $\mathrm{pH} 4.5$ than the $\mathrm{pH} 2.5$ could be attributed to the fact that weak acids have higher antimicrobial activity due to its dissociated form that can freely pass through the cell membrane [13] and it ability to promote undesirable redox reaction which is responsible for the bactericidal effect.

For the selected Gram-negative bacteria, the time-kill measurements showed ineffective antibacterial activities of the acidic, neutral, and alkaline ionized water on E. coli, P. agglomerans, and K. pneumoniae. Throughout the $8 \mathrm{~h}$ period of the test, the log reduction difference in relative to the initial bacteria inoculum for all the $\mathrm{pH}$ tested was $<3 \log 10$, indicating ionized water has no bactericidal effect on the growth inhibition of Gram-negative bacteria. The highest percentage reduction for $E$. coli was observed with $\mathrm{pH} 2.5(50 \%)$ and $\mathrm{pH} 4.5(58 \%)$. The highest percentage reduction for P. agglomerans (26\%-27\%) and K. pneumoniae (47\%-55\%) also observed with acidic ionized water. This finding is similar to an earlier report where alkaline electrolyzed water had no effect on E. coli growth [16]. Although, slightly acidic electrolyze water caused significant inhibition of $E$. coli growth $[8,9]$, in this present study, acidic, neutral, and alkaline ionized water were inadequate to caused a bactericidal effect. The possible reason could be that ionized water when dissociated depending on whether it is acidic or alkaline, it only contains hydrogen ions, hydroxyl ions, and carbonate ions. It does not contain hypochlorous acid, which is one of the factors responsible for the antibacterial effect reported for acidic electrolyze water [17].

More so, E. coli and some other bacteria have been proved to possess the ability to maintain $\mathrm{pH}$ homeostasis $[18,19]$. Low $\mathrm{pH}$ environment favors generation of basic amines through the consumption of acid by enzyme dehydrogenases and decarboxylases with overall decrease in the acidic effect on the bacteria. While in high $\mathrm{pH}$ environment, there is upregulation of deaminases which results in cytoplasmic metabolic generation of ATP synthase, acid, and other important enzymes for the survival of the bacteria [20].

\section{Conclusion}

This study revealed that acidic ionized water at $\mathrm{pH} 2.5$ and 4.5 are effective in minimizing Staphylococcus spp. infection in horse wounds. The acidic ionized water could be of clinical importance 
as antiseptic for surface wound lavage. Therefore, future studies should aim to explain the antibacterial mechanism of ionized water on pathogenic bacteria for better understanding and institution of appropriate therapeutic processes.

\section{Authors' Contributions}

NMA and ZZ conceptualized and designed the study. AZAR and NMA collected the samples and AZAR performed the laboratory analysis. AMM did the data analysis. AZAR and AMM write the original draft. NMA and ZZ reviewed and edited the manuscript. All authors read and approved the final manuscript.

\section{Acknowledgments}

Our sincere gratitude to the management of equine establishments for consenting to the use of their horse and the staff of Bacterial Laboratory, Faculty of Veterinary Medicine UPM. The authors did not receive any funds for this study.

\section{Competing Interests} interests.

The authors declare that they have no competing

\section{Publisher's Note}

Veterinary World remains neutral with regard to jurisdictional claims in published institutional affiliation.

\section{References}

1. Westgate, S.J., Percival, S.L., Knottenbelt, D.C., Clegg, P.D. and Cochrane, C.A. (2011) Microbiology of equine wounds and evidence of bacterial biofilms. Vet. Microbiol., 150(1-2): 152-159.

2. Orsini, J.A. (2017) Update on managing serious wound infections in horses: Wounds involving soft tissues. J. Equine Vet. Sci., 55: 18-26.

3. Bergström, K., Aspan, A., Landén, A., Johnston, C. and Grönlund-Andersson, U. (2012) The first nosocomial outbreak of methicillin-resistant Staphylococcus aureus in horses in Sweden. Acta Vet. Scand., 54(1): 11.

4. Casey, M.L., Hawley, B., Edwards, N., Cox-Ganser, J.M. and Cummings, K.J. (2018) Health problems and disinfectant product exposure among staff at a large multispecialty hospital. Am. J. Infect. Control, 45(10): 1133-1138.

5. Nakae, H. and Inaba, H. (2000) Effectiveness of electrolyzed oxidized water irrigation in a burn-wound infection model. J. Trauma., 49(3): 511-514.

6. Yahagi, N., Kono, M., Kitahara, M., Ohmura, A., Sumita, O., Hashimoto, T., Hori, K., Ning-Juan, C., Woodson, P., Kubota, S., Mukarami, A. and Takamoto, S. (2000) Effect of electrolyzed water on wound healing. Artif. Organs.,
24(4): 363-370.

7. Hao, X., Cao, W., Li, B., Zhang, Q., Wang, C. and Ge, L. (2014) Slightly acidic electrolyzed water for reducing airborne microorganisms in a layer breeding house. J. Air Waste Manag. Assoc., 64(4): 494-500.

8. Ni, L., Zheng, W., Zhang, Q., Cao, W. and Li, B. (2016) Application of slightly acidic electrolyzed water for decontamination of stainless steel surfaces in animal transport vehicles. Prev. Vet. Med., 133: 42-51.

9. Zhang, C., Cao, W., Hung, Y. and Li, B. (2016) Disinfection effect of slightly acidic electrolyzed water on celery and cilantro. Food Control, 69: 147-152.

10. Carnwath, R., Graham, E.M., Reynolds, K. and Pollock, P.J. (2014) The antimicrobial activity of honey against common equine wound bacterial isolates. Vet. J., 199(1): 110-114.

11. Issa-Zacharia, A., Kamitani, Y., Tiisekwa, A., Morita, K. and Iwasaki, K. (2010) In vitro inactivation of Escherichia coli, Staphylococcus aureus and Salmonella spp. using slightly acidic electrolyzed water. J. Biosci. Bioeng., 110(3): 308-313.

12. Li, J., Ding, T., Liao, X., Chen, S., Ye, X. and Liu, D. (2017) Synergetic effects of ultrasound and slightly acidic electrolyzed water against Staphylococcus aureus evaluated by flow cytometry and electron microscopy. Ultrason. Sonochem., 38: 711-719.

13. Cotter, P.D. and Hill, C. (2003) Surviving the acid test: Responses of gram-positive bacteria to low $\mathrm{pH}$. Microbiol. Mol. Biol. Rev., 67(3): 429-453.

14. Nascimento, M.M., Lemos, A.C.J., Abranches, J., Gonçalves, R.B. and Burne, R.A. (2004) Adaptive acid tolerance response of Streptococcus sobrinus. J. Bacteriol., 186(19): 6383-6390.

15. Sanchez, B., Champomier-Verge, M.C., Collado, M.C., Anglade, P., Baraige, F., Sanz, Y., Reyes-Gavilan, C.G., Margolles, A. and Zagorec, M. (2007) Low-pH adaptation and the acid tolerance response of Bifidobacterium longum biotype longum. Appl. Environ. Microbiol., 73(20): 6450-6459.

16. Ovissipour, M., Al-Qadiri, H.M., Sablani, S.S., Govindan, B.N., Al-Alami, N. and Rasco, B. (2015) Efficacy of acidic and alkaline electrolyzed water for inactivating Escherichia coli O104:H4, Listeria monocytogenes, Campylobacter jejuni, Aeromonas hydrophila, and Vibrio parahaemolyticus in cell suspensions. Food Control, 53: 117-123.

17. Ding, T., Xuan, X., Li, J., Chen, S., Liu, D., Ye, X. and Xue, S.J. (2016) Disinfection efficacy and mechanism of slightly acidic electrolyzed water on Staphylococcus aureus in pure culture. Food Control, 60: 505-510.

18. Stancik, L.M., Stancik, D.M., Schmidt, B., Barnhart, D.M., Yoncheva, Y.N. and Slonczewski, J.L. (2002) pH-dependent expression of periplasmic proteins and amino acid catabolism in Escherichia coli. J. Bacteriol., 184(15): 4246-4258.

19. Wilks, J.C., Kitko, R.D, Cleeton, S.H., Lee, G.E., Ugwu, C.S., Jones, B.D., BonDurant, S.S. and Slonczewski, J.L. (2008) Acid and base stress and transcriptomic responses in Bacillus subtilis. Appl. Environ. Microbiol., 75(4): 981-990.

20. Foster, J.W. (2004) Escherichia coli acid resistance: Tales of an amateur acidophile. Nat. Rev. Microbiol., 2(11): 898-907. 